\title{
Development and Quality Evaluation of a Ready to Drink Lacto Juice from Cape Gooseberry Fruits (Physalis peruviana)
}

\author{
Feziwe F. Nkabinde ${ }^{1}$, and Oluwafemi A. Adebo ${ }^{1^{*}}$
}

\begin{abstract}
Fruits are known to possess numerous health benefits while fermentation improves the nutritive value of foods and provides the needed variety of food commodities. This study aimed to develop and produce a lacto beverage with better properties from an underutilized fruit. The fruits were fermented for 3 days at $25-28{ }^{\circ} \mathrm{C}$ while the unfermented juice served as control. The fermented juice was developed into a beverage and subsequently analysed for total phenols (TPs), titratable acidity (TTA), ascorbic acid content (AAC), $\mathrm{pH}$, specific gravity, refractive index, dissolved solids (DS) and microbiological properties. The samples were also evaluated on Fourier Transform Infrared Spectroscopy (FTIR), while stability tests and sensory analyses were also conducted. The results showed significantly ( $\mathrm{p}<0.05)$ higher TPs (304.1 mg GAE/100 ml), AAC (16.4 mgAAE/100ml) and TTA $125 \mathrm{~g} / \mathrm{L}$, for the fermented lacto-juice. The FTIR spectrum of the lacto juice also showed changes on the spectra. The study shows potential of developing this produce into a beverage and can positively impact its utilization.
\end{abstract}

Keywords-gooseberry fruit, fermentation, lacto-beverage, FTIR

\section{INTRODUCTION}

Cape gooseberry fruit (Physalis peruviana) is a berry with smooth waxy orange-yellow skin, containing very small yellowish seeds. It is "tomato like", and 1-2 cm in diameter with a calyx protective husk. It has sweet and sour taste, (the flavour is described to be "tart like") and can be consumed in its raw state or used in the manufacturing of canned fruit, jams, fruit salads and garnish for desserts. The gooseberry fruit contains $15 \%$ soluble solids which are mainly sugar with high levels of fructose and dietary fibre making it very important for diabetics and as a good intestinal regulator [1], [2]. According to studies done by the United States Department of Agriculture (USDA), $100 \mathrm{~g}$ serving of gooseberry fruit contains vitamin $\mathrm{A}, \mathrm{C}, \mathrm{B}_{1}$ and $\mathrm{B}_{3}$ [2]. Cape gooseberry fruit has anti-flammatory and antioxidant properties and used for medical purposes in different countries. In Europe and Africa it is used as an herbal medicine to treat kidney and bladder stones, fluid retention, gout and urinary tract disorder.

The process of fermentation has been used for many centuries in different countries as it is an inexpensive method of

F. Nkabinde was with the Department of Biotechnology and Food Technology, Faculty of Science, University of Johannesburg, P.O. Box 17011, Doornfontein Campus, Gauteng, South Africa.

O. A. Adebo is with the Department of Biotechnology and Food Technology, Faculty of Science, University of Johannesburg, P.O. Box 17011, Doornfontein Campus, Gauteng, South Africa. preservation of fruit and vegetables [3]-[5]. Furthermore, it is also used to improve the nutritional value and sensory properties of food [6]. Fruits such as grapes, apples to name a few have been fermented for preservation using a process called lacto-fermentation. Lactic acid is a natural preservative which inhibits the growth of harmful bacteria, the lactobacillus bacteria convert the starch sugars in fruit and vegetables into lactic acid, and the process of lacto fermentation also preserves the vitamin and enzymes and also enhances the digestibility of the fermented food. This study therefore seeks to develop and produce a ready to drink beverage from Cape gooseberry fruit (Physalis peruviana). The distinct objectives are to evaluate the biochemical properties of the Cape gooseberry fruit before and after fermentation; to develop a ready to drink lacto-juice using Cape gooseberry fruit; and to evaluate the biochemical, microbiological, sensory properties of the developed ready to drink lacto-juice.

\section{MATERIALS AND METHODS}

\section{A. Raw Materials and Sample Preparation}

Cape gooseberry fruits (Physalis peruviana) were purchased from Euroberry Pty, Gauteng, South Africa. These were transported to the Food Processing Laboratory, University of Johannesburg for processing and analysis. All reagents used were of analytical grade and purchased from Sigma Aldrich, Merck and Rochelle Chemicals, South Africa. The fruit juice was extracted by crushing and pressing of the berries using a wooden spoon pressing out the juice then filtered. The juice was divided into two portions; non fermented and fermented juice for 3 days at $30{ }^{\circ} \mathrm{C}$. The non-fermented and lacto-juice were packaged into sterile bottles and stored at $4{ }^{\circ} \mathrm{C}$ prior to analysis. The lacto-juice was used to develop a lacto-beverage.

\section{B. Biochemical Analyses}

The following analyses were carried out on the gooseberry lacto-juice before and after fermentation. The produced ready to drink beverages were equally evaluated.

1. Titratable Acidity (TTA)

The titratable acidity was determined using the method of [7] with modification. $1 \mathrm{ml}$ of sample was weighed and dissolved in $40 \mathrm{ml}$ of distilled water; 3 drops of phenolphthalein indicator was added and titrated against $0.1 \mathrm{~N}$ sodium hydroxide.

2. Total Phenolic Content (TPC)

Total phenols was determined by following a modified 
procedure described by [8] using Folin-Ciocalteu reagent. Gooseberry juice was placed in a test tube with $10 \mathrm{ml}$ extraction solution $\left(50 \%\right.$ methanol $\left./ \mathrm{H}_{2} \mathrm{O}\right)$ according to [9]. The mixture containing $10 \mu \mathrm{l}$ of the gooseberry juice, $50 \mu \mathrm{l}$ of the Folin-Ciocalteu reagent, $200 \mu \mathrm{l}$ of $50 \mathrm{mg} / 100 \mathrm{ml}$ sodium carbonate and $500 \mu \mathrm{l}$ of distilled water in a tube was vortexed for $15 \mathrm{sec}$ and allowed to stand for $30 \mathrm{~min}$ for colour development. Absorbance was measured at $750 \mathrm{~nm}$ and total phenols were estimated from a standard curve drawn with 0-100 $\mu \mathrm{g} / \mathrm{ml}$ of gallic acid and results expressed as gallic acid equivalents (GAE).

3. Ascorbic Acid

The Ascorbic acid was determined using a modified method [10] and was expressed in $\mathrm{mg} / 100 \mathrm{ml}$ of ascorbic acid. $10 \mathrm{ml}$ of sample was weighed into $250 \mathrm{ml}$ conical flask containing $25 \mathrm{ml}$ of $0.5 \%$ oxalic acid and $10 \mathrm{ml}$ of distilled water was added. The mixture was titrated with 2-6-dichlorophenolindophenol (DCPIP) solution in the burette to a pink end point. The vitamin $\mathrm{C}$ concentration in the juice was calculated as follows;

Mass $=$ MR $($ Ascorbic acid $) \times \mathrm{C}($ DCPIP $) \times \mathrm{V}($ DCPIP $)$

Where; MR $=$ Molar mass, $\mathrm{C}-$ Concentration, $\mathrm{V}-$ Volume

4. $\mathrm{pH}$

The $\mathrm{pH}$ of the drink samples was determined using a $\mathrm{pH}$ meter (Mettler Toledo Seven Compact, Switzerland).

5. Dissolved Solids

The dissolved solids of the ready to drink beverages were determined using a modified method [11] using a RA-500N refractometer (Kytoto Electronics MFG.Ltd, Japan), Brix at 20 ${ }^{\circ} \mathrm{C}$. A sample was rested on the refractometer lens and measurement was taken.

6. Fourier Transform Infrared Spectroscopy (FTIR) Analyses

The FTIR spectra of the samples were determined using a method adopted from [12], [13], using a FTIR spectrophotometer [Thermo Scientific Smart iTR, (Attenuated Total Reflectance), Thermo Fisher Scientific Inc. USA]. Samples were placed on the instrument and the spectra were recorded with characteristics peaks in wave numbers from 500 to $4,000 \mathrm{~cm}^{-1}$ at 16 runs per scan.

\section{Microbiological Analyses}

Microbiological analyses were conducted on both gooseberry juice and lacto beverages according to the method illustrated by [14]. Total plant count, yeast and mould, coliforms, Staphylococcus aureus, salmonella and E. coli were tested. Appropriate dilutions were then enumerated for total aerobic plate counts using Nutrient Agar, coliforms using Violet Red Bile Agar and Staphylococcus aureus using Salt Mannitol Agar. All plates were incubated under aerobic conditions at $30^{\circ} \mathrm{C}$ for $24-48 \mathrm{hrs}$. The mean number of colonies counted was expressed as $\log$ colony forming units (cfu)/100 ml.

\section{Stability Testing of Ready to Drink Beverage}

The shelf life was assessed using the accelerated stability test. One sample of the gooseberry ready to drink beverage was placed in a low temperature incubator (Labcon, Air \&Vacuum Technologies, USA) for 5 days at $40{ }^{\circ} \mathrm{C}$. Separation and discoloration was observed visually.

\section{E. Sensory Evaluation of Ready to Drink Beverage}

Sensory evaluation of the ready to drink beverage was conducted using the 5-point hedonic rating method [15]. Samples of the beverage were given to 50 panellists. They were presented with score cards (1-dislike a lot to 5-like a lot) and asked to test the samples for sensory attributes (appearance, aroma, taste, sweetness and texture/mouth-feel). A 5 point Hedonic scale was used, based on the parameters [16]. The average score of each attribute was calculated by dividing the total score with the number of panellists.

\section{F. Statistical Analyses}

A one-way analyses of variance (ANOVA) was performed on data obtained. A t-2 test was performed following (ANOVA) to determine the differences between the fermented and unfermented samples, using IBM SPSS software version 22 (SPSS/IBM, Chicago Illinois). Mean values of samples were deemed to be significantly at probability level of $5 \%$ [17].

\section{RESULT AND DISCUSSION}

\section{A. Biochemical Properties}

The TTA of the fermented and unfermented juice extract are presented in Table I. The TTA of the fermented juice (12.50 $\mathrm{g} / \mathrm{L})$ was significantly $(\mathrm{p}<0.05)$ higher than that of the unfermented $(12.01 \mathrm{~g} / \mathrm{L})$. This increase in the titratable acidity observed in this work corresponds with reports that during lacto-fermentation there's an increase in production of lactic acid. Total phenols of the fermented and unfermented gooseberry extract was expressed as mg gallic acid equivalent (GAE) per $100 \mathrm{ml}$ of sample as shown in Table I. The phenol content of the fermented gooseberry extract was found to be significantly $(\mathrm{p}<0.05)$ higher $(304.1 \mathrm{GAE} \mathrm{mg} / 100 \mathrm{ml})$ than the unfermented gooseberry extract $(176.7 \mathrm{GAE} \mathrm{mg} / 100 \mathrm{ml})$ total phenols. This result agrees with that of [18], fermentation causes an increase in total phenols. Phenolic compounds are bound with sugar are reduce their availability to organisms. But during the fermentation process enzymes hydrolyse complexes of phenolics into soluble-free phenolic and other simpler and biologically active phenols which are readily absorbed [18], [19]. Ascorbic acid is of importance to the human body as it assists the body to absorb iron, aid wounds to heal faster, helps red blood cell formation and help the body to fight against infections. Deficiency in vitamin C leads to an illness known as scurvy which results in the breaking down of tissues in the body causing poor wound healing. The ascorbic acid content of the fermented and unfermented gooseberry extract is presented in Table I. The ascorbic content of the fermented extract (16.4 mgAAE $/ 100 \mathrm{ml})$ was significantly $(\mathrm{p}<0.05)$ higher than that of the unfermented $(15.7 \mathrm{mgAAE} / 100 \mathrm{ml})$. This increase in the ascorbic acid observed in this work corresponds with report which observed that vitamin $\mathrm{C}$ content of citrus pills and white cabbage increased with fermentation [20]. In the study done by [18] they noted that vitamin $\mathrm{C}$ content decreases as the fermentation time increases, he noted that this was due to the increase in the activity of the enzyme ascorbate oxidase that might have been produced by the fermentation microorganisms which depends on the $\mathrm{pH}$ of the fermentation environment to 
convert ascorbic acid to dehydroascorbic acid.

The $\mathrm{pH}$ values of the fermented and unfermented gooseberry juice are presented in Table II. The $\mathrm{pH}$ of the fermented juice (3.70) was significantly $(\mathrm{p}<0.05)$ higher than that of the unfermented (3.88). This decrease in the $\mathrm{pH}$ observed in this work corresponds with report that during lacto-fermentation there's a decrease in $\mathrm{pH}$ during fermentation with the production of lactic acid [20]. The total dissolved solids in the beverage $\left(7.16^{\circ}\right.$ Brix) was slightly significantly $(\mathrm{p}<0.05)$ lower than the fermented juice.

TABLE I

\begin{tabular}{|c|c|c|c|c|c|c|c|}
\hline Sample & $\begin{array}{l}\text { TTA } \\
(\mathrm{g} / \mathrm{L})\end{array}$ & $\begin{array}{l}\text { TPC } \\
\text { (GAE } \\
\mathrm{mg} / \mathrm{ml})\end{array}$ & $\begin{array}{l}\text { Ascorbic } \\
\text { acid } \\
(\mathrm{mg} / 100 \\
\mathrm{ml})\end{array}$ & $\overline{\mathrm{pH}}$ & $\begin{array}{l}\text { TSS } \\
\left({ }^{\circ} \mathrm{Brix}\right. \\
)\end{array}$ & $\begin{array}{l}\text { Refractive } \\
\text { index }\end{array}$ & $\begin{array}{l}\text { Specifi } \\
\text { c } \\
\text { gravity }\end{array}$ \\
\hline $\begin{array}{l}\text { Unfermented } \\
\text { juice }\end{array}$ & $\begin{array}{l}12.01 \\
a \\
(0.16)\end{array}$ & $\begin{array}{l}176.70^{\mathrm{a}} \\
(1.60)\end{array}$ & $\begin{array}{l}15.70^{\mathrm{a}} \\
(0.02)\end{array}$ & $\begin{array}{l}3.88^{\mathrm{a}} \\
(0.01 \\
)^{2}\end{array}$ & $\begin{array}{l}12.87^{\mathrm{a}} \\
(0.01)\end{array}$ & $\begin{array}{l}1.35^{\mathrm{a}} \\
(0.00)\end{array}$ & $\begin{array}{l}1.05^{\mathrm{a}} \\
(0.00)\end{array}$ \\
\hline $\begin{array}{l}\text { Fermented } \\
\text { juice }\end{array}$ & $\begin{array}{l}12.50 \\
b \\
(0.16)\end{array}$ & $\begin{array}{l}304.1^{\mathrm{b}} \\
(0.99)\end{array}$ & $\begin{array}{l}16.40^{\mathrm{b}} \\
(0.05)\end{array}$ & $\begin{array}{l}3.70^{\mathrm{b}} \\
(0.00 \\
\end{array}$ & $\begin{array}{l}12.50^{\mathrm{b}} \\
(0.02)\end{array}$ & $\begin{array}{l}1.35^{\mathrm{b}} \\
(0.00)\end{array}$ & $\begin{array}{l}1.00^{\mathrm{b}} \\
(0.00)\end{array}$ \\
\hline Beverage & $\begin{array}{l}9.60^{\mathrm{a}} \\
(0.02)\end{array}$ & - & - & $\begin{array}{l}3.05^{\mathrm{a}} \\
(0.01\end{array}$ & $\begin{array}{l}7.16^{\mathrm{a}} \\
(0.01)\end{array}$ & $\begin{array}{l}1.32^{\mathrm{a}} \\
(0.00)\end{array}$ & $\begin{array}{l}1.06^{\mathrm{a}} \\
(0.00)\end{array}$ \\
\hline
\end{tabular}

*values in the same column with different letter are significantly $(\mathrm{p}<0.05)$ different

\section{B. FTIR Spectrum}

The FT-IR spectrum of fermented and unfermented Gooseberry extract as shown in Fig. 1 (a) and 1 (b) demonstrates their characteristic band features. A strong absorption band was observed at 3374.91 and $3379.5 \mathrm{~cm}^{-1}$ in both fermented and non-fermented represent the $\mathrm{O}-\mathrm{H}$ stretch, alcohol functional group. The $\mathrm{O}-\mathrm{H}$ stretch for the fermented extract appears to be longer when compared to the non-fermented extract. This can be due to the increase in $\mathrm{OH}$ bonds during the fermentation process. The weak bond at $2122.26 \mathrm{~cm}^{-1}$ and $2107.20 \mathrm{~cm}^{-1}$ represent the $-\mathrm{C} \equiv \mathrm{C}$ stretch, alkynes functional group. The medium absorption peak at 1643.92 and $1644.12 \mathrm{~cm}^{-1}$ correspond to the $-\mathrm{C}=\mathrm{C}-$ and $\mathrm{N}-\mathrm{H}$ stretch of alkenes and amines functional groups. The peak stretched longer in the fermented extract. During the fermentation process there was an increase in the availability of amines which are sub-units of amino acids, due to protein hydrolyses that took place during fermentation breaking down protein into smaller amino acids [21]. The weak absorption peak appeared at $1422.69 \mathrm{~cm}^{-1}$ and $1538.45 \mathrm{~cm}^{-1}$ due to the N-O stretch nitro compounds.

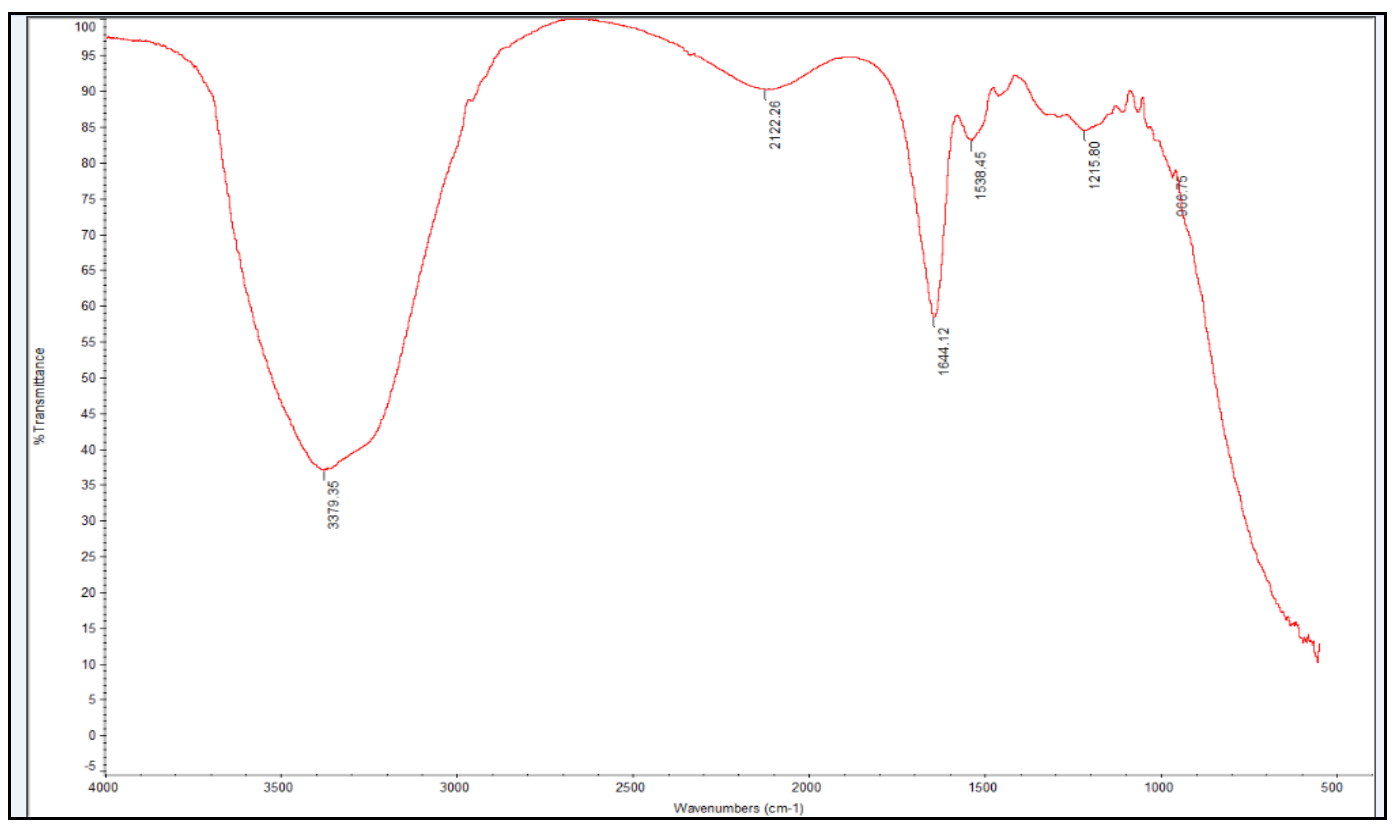

Fig. 1 (a) FTIR Spectrum of unfermented gooseberry juice 


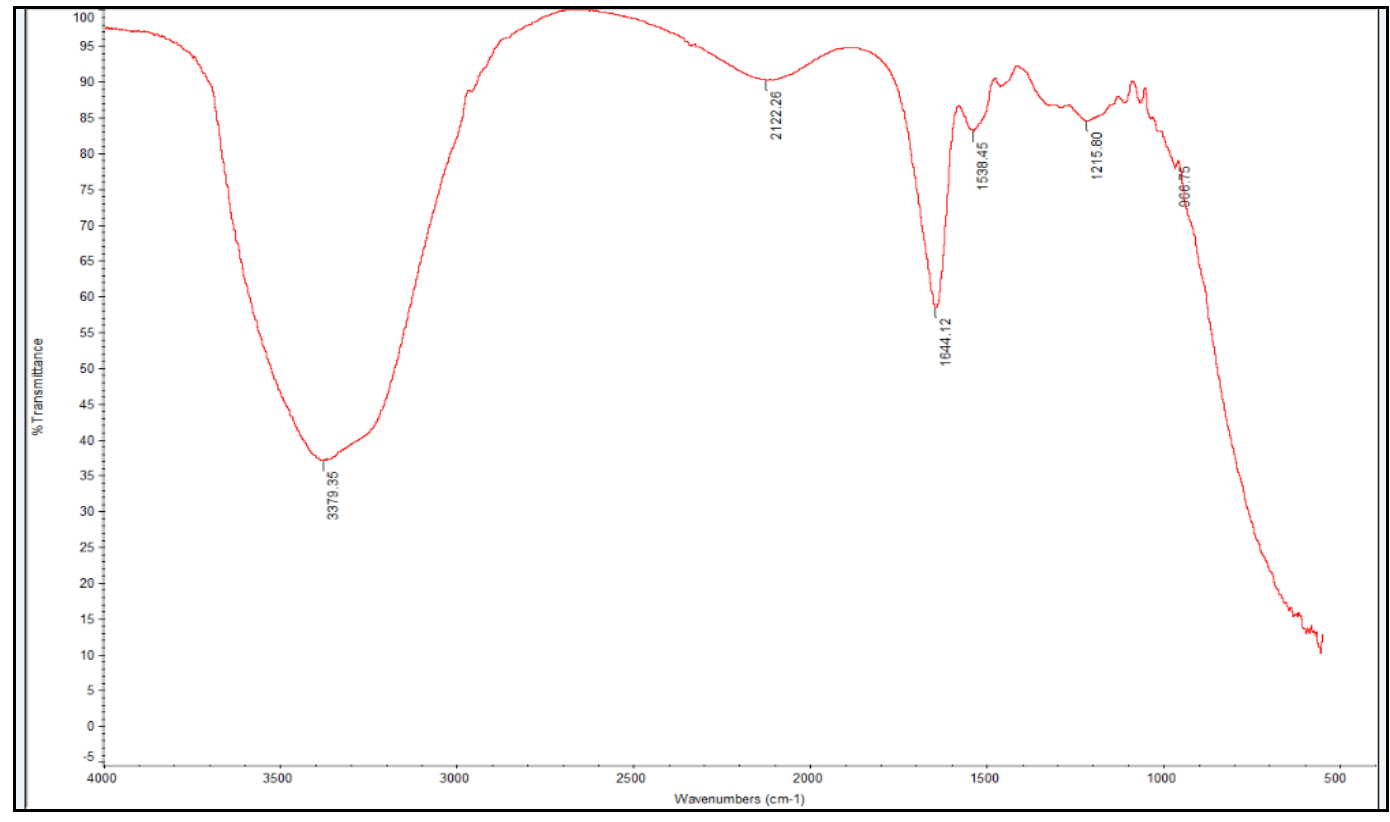

Fig. 1 (b) FTIR Spectrum of fermented gooseberry juice

\section{Microbial Enumeration}

The total aerobic plate count for the fermented juice was higher when compared to the unfermented juice (Table II). This is not surprising, considering the fact that during fermentation, there is usually a succession of various microorganisms, particularly fermenting lactic acid bacteria which might have influenced the increase in the total aerobic counts. Although $E$. coli and Salmonela were not detected in both juices as well as the beverage (Table II), a reduction in the yeast and moulds levels could be due to antagonistic effects of the fermenting microorganisms. Antimicrobial compounds as well as reduced $\mathrm{pH}$ earlier observed (Table I) might have also contributed to this reduction.

TABLE II

MICROBIAL ENUMERATION OF THE FERMENTED AND UNFERMENTED GOOSEBERRY JUICE, AND LACTO-BEVERAGES

\begin{tabular}{llll}
\hline \hline Test criteria & & \multicolumn{2}{c}{ Amount present $(\mathrm{g} / \mathrm{ml})$} \\
& Unfermented juice & Fermented juice & Beverage \\
\cline { 2 - 4 } Total aerobic count & 1000 & $>30,000$ & 20 \\
Escherichia coli & Negative & Negative & Negative \\
Yeast and moulds & $>30,000$ & $>8,000$ & 10 \\
Enterobacteriacea & $<30$ & 10 & $<10$ \\
Staphylococcus & $<10$ & $<10$ & $<10$ \\
aureus & & & \\
Clostridium & $<10$ & $<10$ & $<10$ \\
perfringes & & & \\
Bacillus cereus & Negative & Negative & Negative \\
Salmonella & Negative & Negative & Negative \\
\hline \hline
\end{tabular}

\section{Stability of Ready to Drink Beverages and Sensory Evaluation}

The number of days that the product remains stable at the recommended storage conditions is referred to as the shelf life of the product. After 5 days in the incubator at $40^{\circ} \mathrm{C}$ (a form of accelerated shelf life) the samples were evaluated visually for any colour change and separation. The product was stable and did not show any separation or discolouration. It should be noted that such products are usually refrigerated during storage (at about $4{ }^{\circ} \mathrm{C}$ ), but tests were done at $40{ }^{\circ} \mathrm{C}$ to accelerate the shelf life of the product, which nonetheless yielded positive results. Using the 5 point Hedonic scale the panellists scored the ready to drink beverage, an average score of 4.2 (for appearance), aroma 3.9, taste 3.9, sweetness 4.1 and for texture/mouth feel 4.7 (Table III). On a scale of 5, results obtained suggest the desirability of the beverage based on perception.

TABLE III

\begin{tabular}{lc} 
SENSORY EVALUATION OF THE LACTO-BEVERAGES \\
\hline \hline Sensory parameter & Score for Beverage \\
Appearance & 4.2 \\
Aroma & 3.9 \\
Taste & 3.9 \\
Sweetness & 4.1 \\
Texture/mouth-feel & 4.7 \\
\hline \hline
\end{tabular}

\section{CONCLUSIONS}

The study has shown that the process of fermentation has a potential to increase utilization of indigenous gooseberry fruit. The study showed that lacto-beverages with better composition and properties can be obtained from this fruit. While this study indicated the potential of this fruit, more detailed study into the composition of the product is still needed to further substantiate some of the results obtained in this study.

\section{REFERENCES}

[1] R. McCain, "Goldenberry, passion fruit and white sapote: potential fruits for cool subtropical areas," in: J. Janick and J. E. Simon (Eds.), New crops. New York: Wiley, 1993, pp. 479-486.

[2] M. F. Ramadan, "Bioactive phytochemicals, nutritional value, and functional properties of cape gooseberry (Physalis peruviana): an overview," Food Research International, vol. 44, pp. 1830-1836, 2011. 
https://doi.org/10.1016/j.foodres.2010.12.042

[3] O. A. Adebo, P. B. Njobeh, A. S. Adeboye, J. A. Adebiyi, S. S. Sobowale, O. M. Ogundele and E. Kayitesi, "Advances in Fermentation Technology for Novel Food Products," in: Innovations in Technologies for Fermented Food and Beverage Industries, S. Panda and P. Shetty Eds. Switzerland: Springer, 2018a, pp. 71-87. https://doi.org/10.1007/978-3-319-74820-7_4

[4] J. A. Adebiyi, A. O. Obadina, O. A. Adebo, and K. Eugenie, "Fermented and malted millet products in Africa: Expedition from traditional/ethnic foods to industrial value added products," Critical Reviews in Food Science and Nutrition, vol. 58, pp. 463-474, 2018.

[5] M. R. Swain, M. Anandharaj, R. C. Ray, and R. P. Rani, "Fermented fruits and vegetables of Asia: a potential source of probiotics," Biotechnology Research International, vol. 2014, pp. 1-19, May 2014. https://doi.org/10.1155/2014/250424

[6] N. Demir, K. S. Bahçeci, and J. Acar, "The effects of different initial Lactobacillus plantarum concentrations on some properties of fermented carrot juice," Journal of Food Processing and Preservation, vol. 30, pp. 352-363, 2006 https://doi.org/10.1111/j.1745-4549.2006.00070.x

[7] M. De Marchi, C. C. Fagan, C. P. O'Donnell, A. Cecchinato, R. Dal Zotto, M. Cassandro, M. Penasa, and G. Bittante, "Prediction of coagulation properties, titratable acidity, and $\mathrm{pH}$ of bovine milk using mid-infrared spectroscopy," Journal of Dairy Science, vol. 92, pp. 423-432, 2009

https://doi.org/10.3168/jds.2008-1163

[8] E. A. Ainsworth, and K. M. Gillespie, "Estimation of total phenolic content and other oxidation substrates in plant tissues using Folin-Ciocalteu reagent," Nature Protocols, vol. 2, pp. 875-877, April 2007. https://doi.org/10.1038/nprot.2007.102

[9] G. E. Pantelidis, M. Vasilakakis, G. A. Manganaris, and G. Dimantidis, "Antioxidant capacity, phenol, anthocyanin and ascorbic acid contents in raspberries, blackberries, red currants, gooseberries and Cornelian cherries," Food Chemistry, vol. 102, pp. 777-783, 2007. https://doi.org/10.1016/j.foodchem.2006.06.021

[10] A. Shivembe, and D. Ojinnaka, "Determination of vitamin C and total phenolic in fresh and freeze dried blueberries and the antioxidant capacity of their extracts," Integrative Food, Nutrition and Metabolism, vol. 4, pp. $1-5$, October 2017 https://doi.org/10.15761/IFNM.1000197

[11] S. Graefea, M. Hermannb, I. Manriqueb, S. Golombeka, and A. Buerkerta, "Effects of post-harvest treatments on the carbohydrate composition of yacon roots in the Peruvian Andes," Field Crops Research, vol. 86, pp. 157-165, 2004. https://doi.org/10.1016/j.fcr.2003.08.003

[12] O. A. Adebo, P. B. Njobeh, A. F. Mulaba-Bafubiandi, J. A. Adebiyi, Z. S. C. Desobgo, and E. Kayitesi, "Optimization of fermentation conditions for ting production using response surface methodology," Journal of Food Processing and Preservation, vol. 42, pp. 1-10,2018b. https://doi.org/10.1111/jfpp.13381

[13] S. Kannan, "FT-IR and EDS analysis of the seaweeds Sargassum wightii (brown algae) and Gracilaria corticata (red algae)," International Journal of Current Microbiology and Applied Sciences, vol. 3, pp. 341-351, 2014.

[14] D. P. Mahale, R. G. Khade, and V. K. Vaidya, "Microbiological analysis of street vended fruit juices from Mumbai City, India," Internet Journal of Food Safety, vol. 10, pp. 31-34, 2008.

[15] R. Deliza, and H. J. H. MacFie, "The generation of sensory expectations by external cues and its effects on sensory perceptions and hedonic ratings: a review," Journal of Sensory Studies, vol. 11, pp. 103-128, 1996 https://doi.org/10.1111/j.1745-459X.1996.tb00036.x

[16] H. Kim, L. A. House, A. Z. Odabasi, and C. A. Sims, "Sensory and hedonic evaluation in response to food-cue exposure: the case of juicing demonstration of fresh oranges," International Journal of Marketing Studies, vol. 7, pp. 65-75, September 2015. https://doi.org/10.5539/ijms.v7n5p65

[17] Z. Cvijović, G. Radenković, V. Maksimovic, and B. Dimčić, "Application of ANOVA method to precipitation behaviour studies," Materials Science and Engineering, vol. 397, pp. 195-203, February 2005. https://doi.org/10.1016/j.msea.2005.02.021

[18] F. O. Adetuyi, and T. A. Ibrahim, "Effect of fermentation time on the phenolic, flavonoid and vitamin c contents and antioxidant activities of okra (Abelmoschus esculentus) seeds," Nigerian Food Journal, vol. 32, pp. 128-137, 2014 https://doi.org/10.1016/S0189-7241(15)30128-4

[19] O. A. Adebo, P. B. Njobeh, and E. Kayitesi, "Fermentation by Lactobacillus fermentum strains (singly and in combination) enhances the properties of ting from two whole grain sorghum types," Journal of Cereal Science, vol. 82, pp. 49-56, May 2018c. https://doi.org/10.1016/j.jcs.2018.05.008

[20] G. Oboh, A. O. Ademosun, S. A. Adefegha, and L. Lajide, "Enhancement of antioxidant properties and neuroprotective potentials of citrus peels using Aspergillus niger solid substrate fermentation technology," Fermentation Technology and Bioengineering, vol. 1, pp. 49-61, 2011. https://doi.org/10.1007/s13197-010-0222-y

[21] N. Murekatete, Y. Hua, X. Kong, and C. Zhang, "Effects of fermentation on nutritional and functional properties of soybean, maize, and germinated sorghum composite flour," International Journal of Food Engineering, vol. 8, pp. 1-15, January 2012. https://doi.org/10.1515/1556-3758.2646 